\title{
Severe hypoxia induces chemo-resistance in clinical cervical tumors
} through MVP over-expression Pedro C Lara*1,2, Marta Lloret ${ }^{1,2}$, Bernardino Clavo ${ }^{1,2}$, Rosa M Apolinario ${ }^{2}$, Luis Alberto Henríquez-Hernández ${ }^{2,3}$, Elisa Bordón², Fausto Fontes ${ }^{2}$ and Agustín Rey ${ }^{2,4}$

\author{
Address: ${ }^{1}$ Radiation Oncology Department, Hospital Universitario de Gran Canaria Dr. Negrín, Spain, ${ }^{2}$ Canary Institute for Cancer Research \\ (ICIC), Spain, ${ }^{3}$ Clinic Sciences Department of Las Palmas de Gran Canaria University (ULPGC), Spain and ${ }^{4}$ Pathology Department, Hospital \\ Universitario de Gran Canaria Dr. Negrín, Spain \\ Email: Pedro C Lara* - plara@dcc.ulpgc.es; Marta Lloret - mllosae@hotmail.com; Bernardino Clavo - bclavar@gobiernodecanarias.org; \\ Rosa M Apolinario - rapohid@gobiernodecanarias.org; Luis Alberto Henríquez-Hernández - lhenriquez@dcc.ulpgc.es; \\ Elisa Bordón - elisarbr@gmail.com; Fausto Fontes - faustofontes@gmail.com; Agustín Rey - areylop@gobiernodecanarias.org \\ * Corresponding author
}

Published: 6 August 2009

Radiation Oncology 2009, 4:29 doi:10.1 186/1748-717X-4-29

This article is available from: http://www.ro-journal.com/content/4/I/29

(c) 2009 Lara et al; licensee BioMed Central Ltd.

This is an Open Access article distributed under the terms of the Creative Commons Attribution License (http://creativecommons.org/licenses/by/2.0), which permits unrestricted use, distribution, and reproduction in any medium, provided the original work is properly cited.

\begin{abstract}
Oxygen molecule modulates tumour response to radiotherapy. Higher radiation doses are required under hypoxic conditions to induce cell death. Hypoxia may inhibit the non-homologous end-joining DNA repair through down regulating Ku70/80 expression. Hypoxia induces drug resistance in clinical tumours, although the mechanism is not clearly elucidated. Vaults are ribonucleoprotein particles with a hollow barrel-like structure composed of three proteins: major vault protein (MVP), vault poly(ADP-ribose) polymerase, and telomerase associated protein-I and small untranslated RNA. Over-expression of MVP has been associated with chemotherapy resistance. Also, it has been related to poor outcome in patients treated with radiotherapy alone. The aim of the present study was to assess the relation of Major Vault Protein expression and tumor hypoxia in clinical cervical tumors. MVP, p53 and angiogenesis, together with tumor oxygenation, were determined in forty-three consecutive patients suffering from localized cervix carcinoma. High MVP expression was related to severe hypoxia compared to low MVP expressing tumors $(p=0.022)$. Tumors over-expressing MVP also showed increased angiogenesis $(p=0.003)$. Besides it, in this study we show for the first time that severe tumor hypoxia is associated with high MVP expression in clinical cervical tumors. Up-regulation of MVP by hypoxia is of critical relevance as chemotherapy is currently a standard treatment for those patients. From our results it could be suggested that hypoxia not only induces increased genetic instability, oncogenic properties and metastatization, but through the correlation observed with MVP expression, another pathway of chemo and radiation resistance could be developed.
\end{abstract}

\section{Introduction}

Growing cancers often acquire an increasing number of genetic alterations. Such genetic changes, including chro- mosomal translocation, gene amplification, intragenic mutation, and gene silencing, are responsible for the activation of oncogenes and the inactivation of tumour-sup- 
pressor genes [1]. How cancer cells acquire genetic instability remains unclear. Exposure of cells to adverse conditions like hypoxia can lead to genome alterations, enhancing the progression potential of tumor cells and resistance to oncological treatments [1]. Hypoxia may lead to conditions that causes increased spontaneous damage to DNA or inhibit DNA repair processes, impair DNA repair and cause tumor progression by altered p53 expression and increased angiogenesis $[2,3]$. Deregulation of DNA repair pathways can contribute to the phenomenon of hypoxia-induced genetic instability within the tumor [4]. Hypoxia is measured in clinical tumors by several techniques, including the Eppendorf polarographic method $[2,5]$. In cervical cancer patients, hypoxia is commonly associated to a lesser response to treatment and lower survival rates $[6,7]$. Hypoxic tumors have a significant higher probability of relapse and death [7] and they are resistant to chemotherapy [8]. Chemo-resistance would be mediated by up-regulation of Major Vault Protein (MVP) through the Hypoxia-inducible factor 1 (HIF1 ) as shown in previously studies performed in vitro [9]. Hypoxia inhibits the non-homologous end joining (NHEJ) DNA repair through down-regulating Ku70/80 expression, combined with increased angiogenesis and altered p53 expression [2]. Cervical tumors over-expressing MVP also showed down-regulation of Ku70/80 and BAX [10]. MVP over-expression has been associated with a suppression of NHEJ repair, and subsequent genomic instability [10]. These mechanisms would be responsible for tumor progression in cervical carcinoma. Moreover, MVP over-expression was associated to reduced long-term local control in patients who achieved clinical complete response to radio-chemotherapy [11]. The aim of the present study was to assess the relation between the expression of the Major Vault Protein and tumor hypoxia in clinical cervical tumors.

\section{Methods}

Forty-three consecutive patients suffering from localized cervix carcinoma were prospectively included in this study from July 1997 to September 2001 [2]. Patients were diagnosed and treated by definitive radiation at the Hospital Universitario Materno-Infantil, at the Hospital Universitario Dr. Negrín and at the Hospital Universitario Insular in Las Palmas de Gran Canaria (Spain). Written informed consent was given previously. The study was approved by the Research and Ethics Committee of our institution. The mean age of the patients was $49.48 \pm 12.79$ years (median 48 , range 29-81 years). Fourteen patients had stage I disease, 22 stage II and 7 stage III-IVA. MVP expression was studied by immunohistochemistry in paraffin-embedded $4 \mu \mathrm{m}$ sections incubated for the specific primary antibody (MVP, Neomarkers CA, USA). A secondary biotinated antibody (Dako Detection Kit, LSBA) was incubated for 30 minutes, and peroxidase-streptavidin-biotin complex
(Dako) was used afterward. Staining was revealed by using diaminobenzidine tetra-hydrochloride substrate (DAB Chromogen; Dako), followed by light counterstaining with Harris hematoxylin as previously described [10]. Data of p53 and angiogenesis, estimated by CD-31 staining, were obtained from our files [2]. Paraffin-embedded tissues from tumor biopsies were available from all patients, and the most representative tumor block was used for immunohistochemical analysis. Blocks were handled as previously described and then incubated for the specific secondary antibody (p53, Clon:DO-7, Novocastra Laboratories Ltd., Newcastle upon Tyne, UK; CD-31 Clon:JC/70A, Dako, Carpintería, CA, USA) [2]. The primary antibody was omitted in one section as a negative control in each set of slides. As a positive control, a strong positive tumor for the oncoprotein was used. Tumor oxygenation was measured by an Eppendorf device following standard criteria as previously described $[2,12]$ using a polarographic probe system "pO2 Histograph" (Eppendorf AG, Hamburg, Germany). For each set of measurements obtained from tumor, 200 single $\mathrm{pO} 2$ values were recorded using at least 6 different electrode tracks. Tumor hypoxia data were reanalyzed for detecting cases of severe hypoxia and the percentage of $\mathrm{pO} 2$ values $<2.5 \mathrm{mmHg}$ were obtained from the pooled data and for each individual. Assessment of immunostaining or tumor oxygenation result was blinded to knowledge of the clinical outcome of the patient. Statistical analysis was performed by SPSS 15.0 software.

\section{Results}

All immunohistochemical markers and hypoxia values were known in all 43 cases (Figure 1). MVP expression was considered low (negative/slightly positive) in 23 cases and high (strongly positive) in 20 cases. Data of mean vascular density (MVD) and p53 expression were obtained from our files [2] (Table 1). MVD was $49.62 \pm 33.98 \%$ (median 41\%, range 0-160). P53 expression showed a mean value of $39.15 \pm 27.62 \%$ (median $35 \%$, range 0 $92 \%$ ). Tumor hypoxia was also known in all patients. Mean tumor hypoxic fraction $<2.5 \mathrm{mmHg}$ (HF 2.5) values were $35.89 \pm 26.80$ (median $35.20 \%$, range $0-91.30 \%$ ). MVP expression was independent of clinical and histological variables, except for adenocarcinoma tumors. In fact adenocarcinoma tumors ( 5 cases) included in the present study over-expressed MVP versus 15 out of 38 squamous cancers $(p=0.011)$. Besides, high MVP expression was related to severe hypoxia as determined by higher hypoxic fractions HF $(2.5)(45.82 \pm 28.00 \%)$ compared to low MVP expressing tumors $(27.26 \pm 22.96 \%)(p=0.022)$ (Figure 2a). Tumors over-expressing MVP also showed increased angiogenesis $(65.41 \pm 38.38)$ compared to low expressing cases $(35.89 \pm 22.55)(\mathrm{p}=0.003)$ (Figure $2 \mathrm{~b})$. MVP expression was independent of p53 protein expression. 
Table I: Characteristics of the patients in the study

\begin{tabular}{|c|c|c|c|c|}
\hline Characteristics & $\begin{array}{l}\text { All patients } \\
(\mathrm{n}=43)\end{array}$ & $\begin{array}{l}\text { MVP low } \\
(n=23)\end{array}$ & $\begin{array}{l}\text { MVP high } \\
(n=20)\end{array}$ & $P$ value \\
\hline Age & $\begin{array}{c}49.48 \pm 12.79 \\
(29-81)\end{array}$ & $\begin{array}{c}49.47 \pm 13.68 \\
(29-81)\end{array}$ & $\begin{array}{c}49.50 \pm 12.04 \\
(32-72)\end{array}$ & 0.325 \\
\hline \multicolumn{5}{|l|}{ Stage } \\
\hline 1 & 14 & 5 & 9 & \\
\hline II & 22 & 13 & 9 & \\
\hline III & 7 & 5 & 2 & 0.228 \\
\hline \multicolumn{5}{|l|}{ Histology } \\
\hline Epidermoid & 38 & 23 & 15 & \\
\hline Adenocarcinoma & 5 & 0 & 5 & 0.011 \\
\hline \multicolumn{5}{|l|}{ Grade } \\
\hline I & 5 & 3 & 2 & \\
\hline ॥ & 19 & 10 & 9 & \\
\hline III & 19 & 10 & 9 & 0.952 \\
\hline \multirow[t]{2}{*}{ p53 } & $39.15 \pm 27.62$ & $37.53 \pm 28.04$ & $41.02 \pm 27.74$ & \\
\hline & $(0-92)$ & $(0-92)$ & $(0-8 I)$ & 0.685 \\
\hline \multirow[t]{2}{*}{ Vascular density } & $49.62 \pm 33.98$ & $35.89 \pm 22.55$ & $65.41 \pm 38.38$ & \\
\hline & $(0-160)$ & $(0-113)$ & $(12-160)$ & 0.003 \\
\hline \multirow[t]{2}{*}{ Hypoxic fraction } & $35.89 \pm 26.80$ & $27.26 \pm 22.96$ & $45.82 \pm 28.00$ & \\
\hline & $(0-91.30)$ & $(0-66.30)$ & (0-91.30) & 0.022 \\
\hline \multirow[t]{2}{*}{ Median $\mathrm{pO}_{2}$} & $7.61 \pm 8.98$ & $7.84 \pm 7.85$ & $7.36 \pm 10.34$ & \\
\hline & $(0-41.90)$ & $(0-24.30)$ & $(0-41.90)$ & 0.863 \\
\hline
\end{tabular}

Mean \pm standard deviation and range are included as well as $\mathrm{p} 53$, vascular density, hypoxic fraction and median of $\mathrm{pO}_{2}$

\section{Discussion}

In this study we show for the first time that severe tumor hypoxia is related to high MVP expression in clinical cervical tumors. MVP is ubiquitously expressed and, besides chemotherapy resistance, it has been implicated in the regulation of several cellular processes including transport mechanisms, signal transmissions and immune responses [13]. Previous studies have demonstrated that vaults are up-regulated in different multidrug resistant cancer cell lines [14] and resistance models $[15,16]$. Increased levels of MVP have been reported in numerous cell lines after selection with a wide panel of cytostatic drugs (e.g. doxorubicin, methotrexate, vincristine or cisplatin) [17]. By contrast, tumour necrosis factor-either applied externally or after gene transduction, led to down-regulation of MVP transcription [18]. There are several publications concern- ing to the relationship between MVP expression and drug resistance in clinical oncology [19-22]. The role of MVP in clinical outcome after radio-chemotherapy in cervical carcinoma [11] and other cancers [23] has been reported. MVP seems to down-regulate the pro-apoptotic gene BAX through its relation with Ku70/80. Ku70/80 are key genes in the NHEJ repair pathway for radiation-induced DNA double strand breaks. Expression of Ku70/80 has been related to survival in patients treated with $\mathrm{x}$-rays $[24,25]$. $\mathrm{Ku} 70 / 80$ is a central regulator of apoptosis by interacting with BAX [26] and BCL-2, which in turn has been shown to suppress $\mathrm{Ku}$, thus inhibiting NHEJ repair [27]. In the clinical setting, up-regulation of MVP by hypoxia is of critical relevance because chemotherapy is currently a standard treatment for those patients. In the other hand, hypoxia inhibits the NHEJ DNA repair through down-reg- (a)

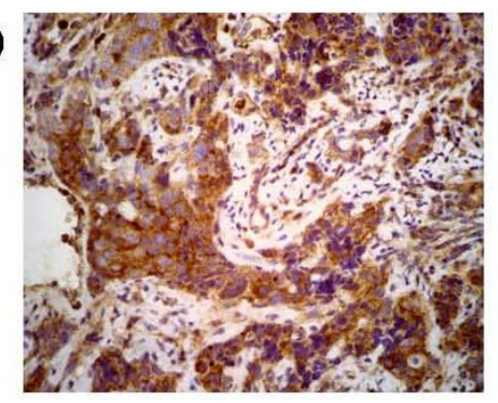

(b)

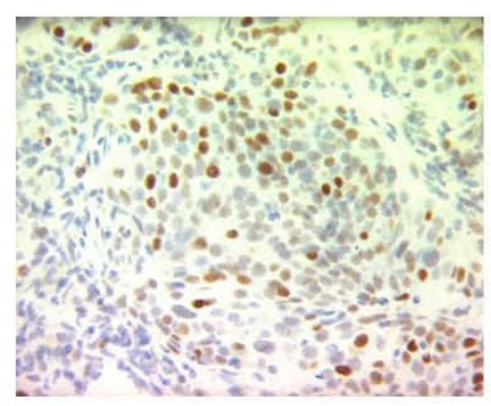

(c)

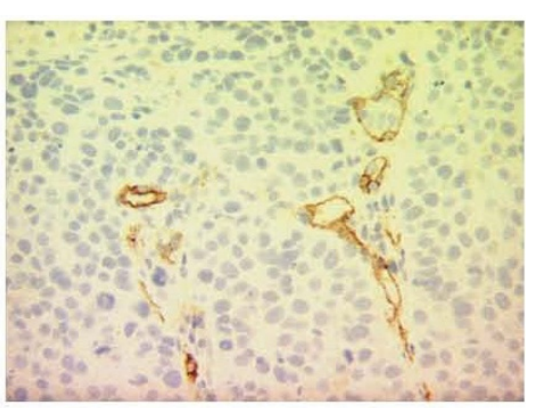

Figure I

Representative immunostaining of MVP (a), p53 (b) and micro-vessels (c). 

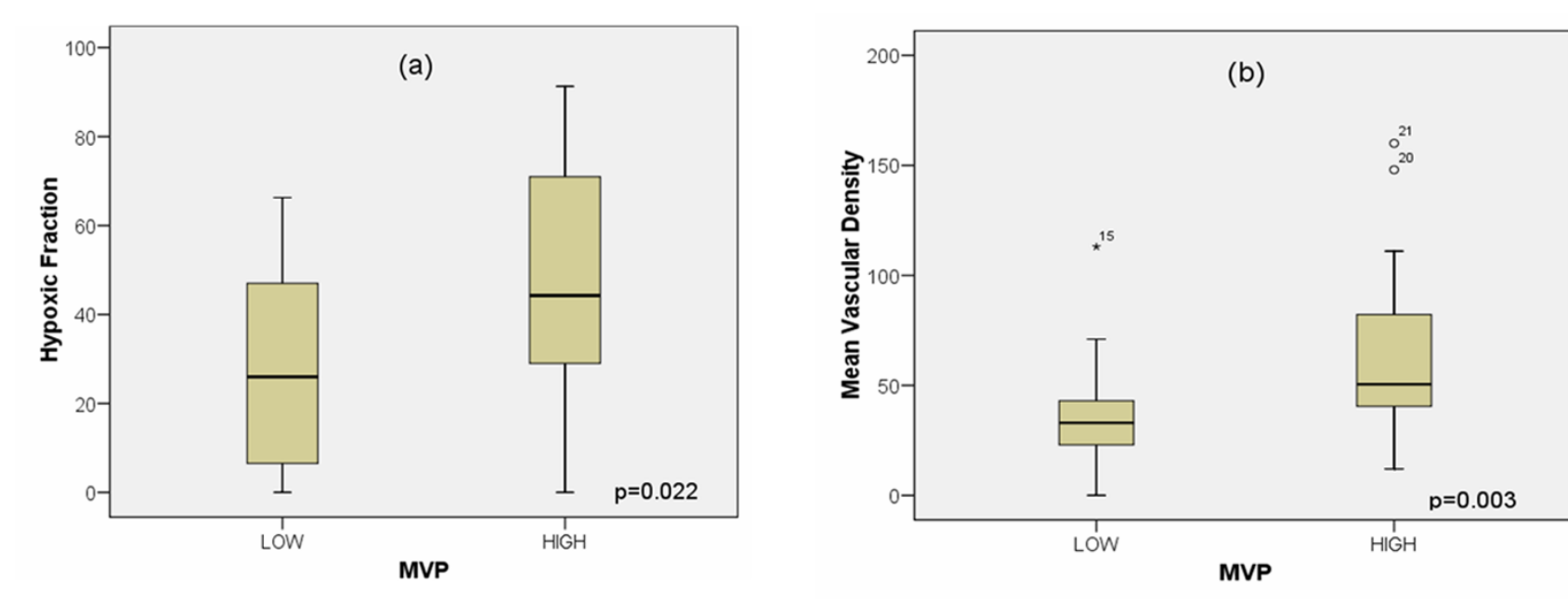

Figure 2

Relationship between (a) MVP and hypoxic fraction (HF 2.5) and (b) mean vascular density.

ulating Ku70/80 expression [2]. Preclinical studies about the role of hypoxia in cancer cells showed that reduction of $\mathrm{pO}_{2}$ is a favoring factor to increase chemo-resistance $[8,28]$. In cancer, hypoxia is an adverse prognostic indicator associated with tumor progression and resistance to therapy [29]. Cellular drug delivery and uptake in hypoxic areas are affected by hypoxia. Some chemotherapeutic drugs require oxygen to generate free radicals that contribute to cytotoxicity. Hypoxia induces cellular adaptations that compromise the effectiveness of chemotherapy. Moreover, the expression of several genes controlling tumor cell survival is regulated by hypoxia (e.g., growth factors governing the formation of new blood vessels and hypoxia-responsive transcription factors modulating the expression of genes). The transcription factor Hypoxiainducible factor 1 (HIF-1) is one of the principal mediators of homeostasis in human tissues exposed to hypoxia. It is implicated in virtually every process of rapid gene expression in response to low oxygen levels [30]. HIF1alpha is over-expressed in the majority of common human cancers and their metastases, due to the presence of intratumoral hypoxia and as a result of mutations in genes encoding oncoproteins and tumor suppressor genes [31,32]. Whether in clinical tumors this chemo-resistance can be reverted by HIF-1 inhibitors deserves to be studied [9]. Pharmacologic manipulation of HIF-1 levels may provide a novel therapeutic approach to diseases like cancer, especially in combination with anti-angiogenic agents [33] that would further reduce tumour oxygenation. Our previously clinical results showed a close relation of clinical hypoxia to increased angiogenesis and in a lesser extent to p53 oncoprotein alteration [2]. Clinical outcome in patients suffering different types of tumours mainly treated by radiation (i.e., cervical and head $\&$ neck can- cers) depends, at least in part, of those parameters. An increased genetic instability, oncogenic properties, resistance to treatment and increased ability to metastization are expected.

From our results it could be suggested that hypoxia not only induces increased genetic instability, oncogenic properties and metastatization, but through the correlation observed with MVP expression, another pathway of chemo-resistance could be developed.

\section{Abbreviations}

HIF-1: Hypoxia-inducible factor 1; MVD: Mean vascular density; MVP: Major Vault Protein; NHEJ: non-homologous end joining.

\section{Conflict of interests}

The authors declare that they have no competing interests.

\section{Authors' contributions}

PCL has been involved in conception and design of the study as well as in drafting the manuscript, and has given final approval of the version to be published. MLl has made the measurements of tumour hypoxia and has treated all patients. $\mathrm{BC}$ has made the measurements of tumour hypoxia. RMA has made the angiogenesis studies. LAHH has been involved in the writing of the manuscript and type of packaging likewise in the submission process. EB has made the MVP studies. FF has made the p53 studies. AR has reviewed and overlooked all the immunohistochemistry experiments. 


\section{Acknowledgements}

This work was subsidized by grants: FIS 1035/98, 0855/0I. HenríquezHernández LA, Bordón $E$ and Fontes $F$ were supported by an educational grant from the Instituto Canario de Investigación del Cáncer (ICIC).

\section{References}

I. Huang LE, Bindra RS, Glazer PM, Harris AL: Hypoxia-induced genetic instability - a calculated mechanism underlying tumor progression. J Mol Med 2007, 85: | 39- I48.

2. Lara PC, Lloret M, Clavo B, Apolinario RM, Bordon E, Rey A, Falcon O, Alonso AR, Belka C: Hypoxia downregulates Ku70/80 expression in cervical carcinoma tumors. Radiother Oncol 2008 89:222-226.

3. Wood RD: DNA repair in eukaryotes. Annu Rev Biochem 1996, 65: $135-167$

4. Bindra RS, Crosby ME, Glazer PM: Regulation of DNA repair in hypoxic cancer cells. Cancer Metastasis Rev 2007, 26:249-260.

5. Tatum JL, Kelloff GJ, Gillies RJ, Arbeit JM, Brown JM, Chao KS, Chapman JD, Eckelman WC, Fyles AW, Giaccia A], Hill RP, Koch CJ, Krishna MC, Krohn KA, Lewis JS, Mason RP, Melillo G, Padhani AR, Powis G, Rajendran JG, Reba R, Robinson SP, Semenza GL, Swartz HM, Vaupel P, Yang D, Croft B, Hoffman J, Liu G, Stone H, Sullivan D: Hypoxia: importance in tumor biology, noninvasive measurement by imaging, and value of its measurement in the management of cancer therapy. Int J Radiat Biol 2006, 82:699-757.

6. Hockel M, Schlenger K, Aral B, Mitze M, Schaffer U, Vaupel P: Association between tumor hypoxia and malignant progression in advanced cancer of the uterine cervix. Cancer Res 1996, 56:4509-45I5

7. Fyles AW, Milosevic M, Wong R, Kavanagh MC, Pintilie M, Sun A Chapman W, Levin W, Manchul L, Keane TJ, Hill RP: Oxygenation predicts radiation response and survival in patients with cervix cancer. Radiother Oncol 1998, 48:149-156.

8. Sasabe E, Zhou X, Li D, Oku N, Yamamoto T, Osaki T: The involvement of hypoxia-inducible factor-Ialpha in the susceptibility to gamma-rays and chemotherapeutic drugs of oral squamous cell carcinoma cells. Int J Cancer 2007, I 20:268-277.

9. Lelong-Rebel I, Brisson C, Fabre M, Bergerat JP, Rebel G: Effect of pO2 on antitumor drug cytotoxicity on MDR and non-MDR variants selected from the LoVo metastatic colon carcinoma cell line. Anticancer Res 2008, 28:55-68.

10. Lloret M, Lara PC, Bordon E, Fontes F, Rey A, Pinar B, Falcon O: Major vault protein may affect nonhomologous end-joining repair and apoptosis through Ku70/80 and bax downregulation in cervical carcinoma tumors. Int J Radiat Oncol Biol Phys 2009, 73:976-979.

II. Lloret M, Lara PC, Bordon E, Rey A, Falcon O, Apolinario RM, Clavo $B$, Ruiz A: MVP expression is related to IGFI-R in cervical carcinoma patients treated by radiochemotherapy. Gynecol Oncol 2008, I I 0:304-307.

12. Clavo B, Perez JL, Lopez L, Suarez G, Lloret M, Morera J, Macias D, Martinez JC, Santana M, Hernandez MA, Robaina F, Gunderoth M: Influence of haemoglobin concentration and peripheral muscle pO2 on tumour oxygenation in advanced head and neck tumours. Radiother Oncol 2003, 66:7I-74.

13. Berger W, Steiner E, Grusch M, Elbling L, Micksche M: Vaults and the major vault protein: novel roles in signal pathway regulation and immunity. Cell Mol Life Sci 2009, 66:43-6I.

14. Izquierdo MA, Shoemaker RH, Flens MJ, Scheffer GL, Wu L, Prather $T R$, Scheper RJ: Overlapping phenotypes of multidrug resistance among panels of human cancer-cell lines. Int J Cancer 1996, 65:230-237.

15. Izquierdo MA, Scheffer GL, Flens MJ, Shoemaker RH, Rome LH, Scheper RJ: Relationship of LRP-human major vault protein to in vitro and clinical resistance to anticancer drugs. Cytotechnology 1996, 19:191-197.

16. Siva AC, Raval-Fernandes S, Stephen AG, LaFemina MJ, Scheper RJ, Kickhoefer VA, Rome LH: Up-regulation of vaults may be necessary but not sufficient for multidrug resistance. Int $J$ Cancer 2001, 92: 195-202.

17. Lange $\mathrm{C}$, Walther $\mathrm{W}$, Schwabe $\mathrm{H}$, Stein U: Cloning and initial analysis of the human multidrug resistance-related MVP/LRP gene promoter. Biochem Biophys Res Commun 2000, 278: I25-I33.
18. Stein U, Walther W, Laurencot CM, Scheffer GL, Scheper RJ, Shoemaker RH: Tumor necrosis factor-alpha and expression of the multidrug resistance-associated genes LRP and MRP. J Nat Cancer Inst 1997, 89:807-8|3.

19. Mossink MH, van Zon A, Scheper RJ, Sonneveld P, Wiemer EA: Vaults: a ribonucleoprotein particle involved in drug resistance? Oncogene 2003, 22:7458-7467.

20. Suprenant KA: Vault ribonucleoprotein particles: sarcophagi, gondolas, or safety deposit boxes? Biochemistry 2002, $41:$ | $4447-\mid 4454$

21. Steiner E, Holzmann K, Elbling L, Micksche M, Berger W: Cellular functions of vaults and their involvement in multidrug resistance. Curr Drug Targets 2006, 7:923-934.

22. Izquierdo MA, Scheffer GL, Schroeijers AB, de Jong MC, Scheper RJ: Vault-related resistance to anticancer drugs determined by the expression of the major vault protein LRP. Cytotechnology 1998, 27: I37-| 48.

23. Silva P, West CM, Slevin N, Valentine H, Ryder WD, Hampson L, Bibi R, Sloan P, Thakker N, Homer J, Hampson I: Tumor expression of major vault protein is an adverse prognostic factor for radiotherapy outcome in oropharyngeal carcinoma. Int J Radiat Oncol Biol Phys 2007, 69: 133-140.

24. Beskow C, Kanter L, Holgersson A, Nilsson B, Frankendal B, AvallLundqvist $E$, Lewensohn $R$ : Expression of DNA damage response proteins and complete remission after radiotherapy of stage IB-IIA of cervical cancer. Br J Cancer 2006, 94:1683-1689.

25. Wilson CR, Davidson SE, Margison GP, Jackson SP, Hendry JH, West CM: Expression of Ku70 correlates with survival in carcinoma of the cervix. BrJ Cancer 2000, 83:1702-1706.

26. Amsel AD, Rathaus M, Kronman N, Cohen HY: Regulation of the proapoptotic factor Bax by Ku70-dependent deubiquitylation. Proc Natl Acad Sci USA 2008, 105:5 I I 7-5 I 22.

27. Wang Q, Gao F, May WS, Zhang Y, Flagg T, Deng X: Bcl2 negatively regulates DNA double-strand-break repair through a nonhomologous end-joining pathway. Mol Cell 2008, 29:488-498.

28. Cosse JP, Michiels C: Tumour hypoxia affects the responsiveness of cancer cells to chemotherapy and promotes cancer progression. Anticancer Agents Med Chem 2008, 8:790-797.

29. Shannon AM, Bouchier-Hayes DJ, Condron CM, Toomey D: Tumour hypoxia, chemotherapeutic resistance and hypoxiarelated therapies. Cancer Treat Rev 2003, 29:297-307.

30. Adams JM, Difazio LT, Rolandelli RH, Lujan J], Hasko G, Csoka B, Selmeczy Z, Nemeth ZH: HIF-I: a key mediator in hypoxia. Acta Physiol Hung 2009, 96:19-28.

31. Semenza GL: Expression of hypoxia-inducible factor I: mechanisms and consequences. Biochem Pharmacol 2000, 59:47-53.

32. Zhong H, De Marzo AM, Laughner E, Lim M, Hilton DA, Zagzag D, Buechler $P$, Isaacs WB, Semenza GL, Simons JW: Overexpression of hypoxia-inducible factor Ialpha in common human cancers and their metastases. Cancer Res 1999, 59:5830-5835.

33. Bergers G, Javaherian K, Lo KM, Folkman J, Hanahan D: Effects of angiogenesis inhibitors on multistage carcinogenesis in mice. Science 1999, 284:808-8|2.

Publish with Bio Med Central and every scientist can read your work free of charge

"BioMed Central will be the most significant development for disseminating the results of biomedical research in our lifetime. "

Sir Paul Nurse, Cancer Research UK

Your research papers will be:

- available free of charge to the entire biomedical community

- peer reviewed and published immediately upon acceptance

- cited in PubMed and archived on PubMed Central

- yours - you keep the copyright
BioMedcentral 